\author{
EISSN:2706-7920 ISSN: 2077-4435 \\ DOI: $10.36632 / \mathrm{csi} / \mathbf{2 0 2 1 . 1 0 . 3 . 3 8}$ \\ Journal homepage: www.curresweb.com \\ Pages: 434-446
}

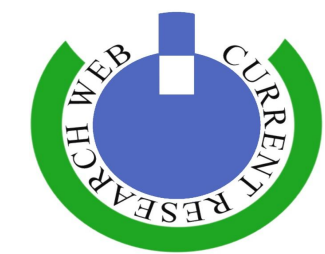

\title{
Effect of Cultivar and Some Processing Treatments on the Quality and Preservation Period of Garlic
}

\author{
${ }^{I}$ Department of Horticultural Crops Tech. Res., Food Tech. Res. Inst., Agricultural Research Center \\ (ARC), Giza, Egypt. \\ ${ }^{2}$ Potato and Vegetatively Propagated Vegetables Dept., Horticulture Research Institute (HRI), \\ Agricultural Research Center (ARC), Giza, Egypt.
}

Received: 15 May 2021 Accepted: 25 July $2021 \quad$ Published: 30 August 2021

\begin{abstract}
This study was conducted to investigate the effects of garlic cultivars (Balady, Chinese, and Sids-40) and some edible coating treatments (T1: Carrageenan + potassium sorbate, T2: Chitosan + potassium sorbate, T3: Chitosan +Carrageenan + potassium sorbate and control), and different cold storage periods on the yield, bulb quality, and preservation period of under consideration cultivars of garlic. The results showed that the Sids-40 cultivar was the highest yield, bulb weight, and bulb diameter after curing. Also, Chinese and Sids-40 cultivars achieved the highest values of cloves weight/ bulb. While Balady cultivar was recorded the highest values of cloves number. Balady cultivar was scored lower values of sprouting and decay percentages than Chinese and Sids-40 cultivars. The chemical analysis of different garlic cultivars, edible coating treatments, and different cold storage periods were studied. The obtained results were indicated that the Chinese cultivar had the highest moisture content followed by the Sids- 40 cultivar. While the lowest moisture content was recorded by Balady cultivar, meanwhile, it was recorded the highest amount of carbohydrate, fat, and ash, respectively. On the other hand, Sids-40 had the highest value of protein content. According to the results of garlic cultivars, combined with the effects of different cold storage periods and edible coating treatmentsmaintained quality attributes and shelf life of peeled garlic cloves compared with the control sample. Based on our results, some of the functional compounds of garlic were also influenced by storage period, garlic cultivars, and edible coating treatments and they had a positive effect on the keeping of all physicochemical and microbial quality parameters for a longer storage period reached to 270 days. It was noticed that treatment No. (3) was the most effective treatment until the end of cold storage periods for all garlic cultivars especially, Balady cultivar. Moreover, results suggested that the treatment (Chitosan + Carrageenan in addition to potassium sorbate) at cold storage conditions could be a promising treatment for extending the storage period and maintaining postharvest quality of peeled garlic cloves especially, for Balady and Sids-40 cultivars.
\end{abstract}

Keywords: Garlic cultivars, (Balady, Sids-40, and Chinese) edible coating treatments, (Chitosan, Carrageenan, and potassium sorbate) and cold storage periods.

\section{Introduction}

Garlic (Allium sativum L.) belongs to the family Alliaceae. It is considered as one of the twenty most important vegetables around the world and the most important one in Egypt, it is winter crops grown in all parts of Egypt, but the most production (yield and quality) located in Upper Egypt and new reclaimed land. Garlic has various uses throughout the world. It's commonly used as a spice as a vegetable for culinary purposes, also, in traditional medicine garlic has innumerable biological activities including immunomodulation. Moreover, a wide range of plant pathogenic bacteria and fungi was inhibited by garlic bulb extracts. To keep the quality of garlic, people used to store garlic in different methods. The quality characteristics of garlic that complement the general criteria for U.S. Grade1 were described by Cantwell, (2003). 
Maintaining garlic in the state of dormancy for a long time is considered the important way of the employed technology for storing. Several treatments (storage system) were investigated to reduce garlic deterioration after harvest. A new attitude takes place for processed garlic marketing to the consumer after peeling and treating with some coating agents. Edible coatings are materials that form a thin layer on the surface of the food. (Dhall, 2013) mentioned that, edible coatings are protein, polysaccharide, or lipid-based. By using edible coatings, the storability of perishable crops can be prolonged. Thus, when edible coating applied to fresh fruits is able to reduce quality changes and slow down quantity losses, e.g., moisture loss by controlling and modifying the internal atmosphere of the individual fruits (Turhan, 2009). Edible coating is a healthy and environment-friendly approach. It is directly consumable and doesn't leave any residues.

Chitosan coating is successfully used as an active packaging material and therefore the antimicrobial films for the good quality of agricultural products, especially fruits and vegetables (Xing et al., 2010, Yage Xing et al., 2016). Meanwhile, Karbowiak et al., (2007) reported that carrageenan is an anionic linear polysaccharide that is derived from red seaweed. There are three kinds of carrageenan as kappa, iota, and lambda with different numbers and positions of sulfate groups on the galactose dimer. Carrageenan is created by gelation through a process of moderate drying. After evaporation of the solvent, the polysaccharide double helices will form a threedimensional network, which subsequently forms a solid film.

The effect of cultivars on garlic yield and its components were studied by some investigators. In this respect, Dawood, (2011) mentioned that, Sids-40 cultivar showed the highest bulb weight with a smaller number of cloves per bulb, clove weight, and total yield, meanwhile, the weight loss percentage was within the Balady cultivar, followed by Sids-40 cultivar, but the differences were insignificant. Abdel-Razzak and El-Sharkawy, (2013) showed that Balady cultivar recorded the highest values of total yield, while there was no significant variation between the two cultivars in N, $\mathrm{P}$, and $\mathrm{K}$ concentration in bulb tissues. However, Chinese cultivar recorded the highest values of clove weight. Osman (2015) founded that the highest values of bulb weight and clove weight were observed with Sids-40 cultivar. However, Balady cultivar produced a markedly higher clove number per bulb than Sids-40 cultivar. Hence, this investigation was conducted to find out the effect of garlic cultivars, different edible coating materials, and cold storage periods on yield and its components, chemical composition, reducing storage losses, and extension of garlic shelf life.

\section{Materials and Methods}

\subsection{Materials}

The experiment was carried out during 2018/2019 and 2019/2020 seasons at Kaha Vegetable Research Farm, Kaluobia Governorate, Horticultural Research Institute and Horticultural Crops Technology Research Department, Food Technology Research Institute, Agricultural Research Center (ARC), Giza, Egypt. The cloves were planted within the last week of September using a randomized complete blocks design with three replicates. The experimental plot was $10.50 \mathrm{~m}^{2}$ which contained 3 rows, with $5 \mathrm{~m}$ length and $0.70 \mathrm{~m}$ width. Garlic cloves were planted on each side of the rows at $10 \mathrm{~cm}$ apart. All agricultural practices for cultivation were applied as recommended by the Ministry of Agriculture, Egypt.

After curing of bulbs, the three cultivars of garlic (Allium sativum L.) Balady, Chinese and Sids-40 were provided from Kaha Research Farm, Kalyobia Governorate during the winter seasons of $2018 / 2019$ and $2019 / 2020$, then, they were kept in the refrigerator at $\left(4^{\circ} \mathrm{C}\right)$ until experiments were carried out. Carrageenan and Chitosan were purchased from United Co., Egypt. Potassium sorbate was purchased from El-Nasr pharmaceutical chemicals Co., Egypt.

\subsection{Data were recorded as follows:}

Yield and its components: after the curing period for 21 days under shaded place, plants of each experimental plot were weighed and total cured yield was calculated as a ton per feddan. Five bulbs were randomly taken from each experimental plot to detect the averages of bulb weight (g), neck and bulb diameter $(\mathrm{cm})$, bulbing ratio, and cloves number per bulb and clove weight $(\mathrm{g})$. 


\section{Storability}

After curing, two kilograms of cured bulbs without stem were randomly taken from each experimental plot in both seasons and placed in plastic nets and stored at room temperature $\left(25 \pm 2^{\circ} \mathrm{C}\right)$. Sprouting and decay of cloves were determined at the end of storage period without any treatments as follows:

$$
\begin{aligned}
\text { Percentage of sprouting } & =\frac{\text { No. of sprouted cloves }}{\text { No. of total cloves }} \times 100 \\
\text { Percentage of decay } & =\frac{\text { No. of decay cloves }}{\text { No. of total cloves }} \times 100
\end{aligned}
$$

\subsection{Technological methods}

\section{Preparation and application of edible coatings}

Chitosan coating solution was prepared according to the method of Jiang et al., (2005). Carrageenan coating solution was prepared according to the method of Ribeiro et al., (2007) with minor modification. Carrageenan coating solutions $(0.25 \%)$ were prepared by dissolving $0.25 \mathrm{~g}$ of carrageenan powder in $100 \mathrm{ml}$ distilled water at $70^{\circ} \mathrm{C}$ for $10 \mathrm{~min}$ under magnetic stirring. Potassium sorbate $(0.15 \mathrm{~g})$ was separately added to the abovementioned solutions to supply antimicrobial coating solutions.

\subsection{Experimental design}

Fresh garlic samples were peeled, then, divided into equal three treatments and immerged in different aqueous edible coating solutions for 30 seconds as follow: -

1- Control sample (without any treatments).

2- (T1) Carrageenan + potassium sorbate.

3- (T2) Chitosan + potassium sorbate.

4- (T3) Chitosan + Carrageenan + potassium sorbate.

Different coating samples in addition to control sample were air-dried for 5 minutes then, placed in plastics bags under vacuum and stored at room temperature under darkness conditions. Both coated and uncoated garlic samples were withdrawn at intervals of 90 days for analysis.

\subsection{Analytical methods}

I. Chemical analysis

Fresh and coated garlic samples were analyzed for moisture, ash, fat, protein contents and total soluble solids (TSS) according to the methods of (AOAC. 2012). Carbohydrate content was estimated by difference.

\section{Determination of pungency}

Pungency quantified as pyruvic acid content using the colorimetric method described by Schwimmer and Weston (1961). The pungency was assessed by the sodium pyruvate standard curve. The results were expressed in $\mu \mathrm{mol}$ of pyruvic acid per $\mathrm{ml}$ of garlic juice.

\subsection{Physical analysis}

\section{Texture analysis}

Both coated and uncoated garlic samples firmness was measured by a universal testing machine (Cometech, B type, Taiwan). A Flathead stainless cylindrical probe of two mm diameter was used for the penetration test. The start of the penetration test was the contact of the probe and sample surface, finish when the probe penetrated the tissues to $50 \%$ of sample height. The probe speed was $1 \mathrm{~mm} \mathrm{~s}^{-1}$. (Bourne, 2002) the values are expressed as Newton (N).

\section{Weight loss}

Weight loss of both coated and uncoated garlic samples was determined gravimetrically using analytical balance during the storage period (Han et al., 2004) by monitoring the weight changes of pods during storage periods. Weight loss was calculated as a percentage loss of initial weight using the subsequent equation 


$$
\text { Weight loss } \%=\frac{\text { Initial garlic lobes weight- final garlic lobes weight }}{\text { Initial garlic lobes weight }} \times 100
$$

\section{Microbiological analysis}

Total viable bacterial count, psychrophilic bacteria, molds, and yeasts were determined using the methods by American Public Health Association (2001). All the microbiological counts were administered in three replicates. The plates were incubated at $37^{\circ} \mathrm{C}$ for 48 hours (total viable bacteria), $7^{\circ} \mathrm{C}$ for $5-7$ days (psychrophilic bacteria), and $25^{\circ} \mathrm{C}$ for 3 days (yeasts and molds). The results were expressed as $(\mathrm{CFU} / \mathrm{g})$.

\subsection{Statistical analysis}

The data were analyzed by analysis of variance (ANOVA). The least significant differences were calculated at $p<0.05$ and Duncan's multiple range test was applied to compare between means (Gomez and Gomez, 1984).

\section{Results and Discussion}

\subsection{Yield and its components.}

Data in Table (1) show significant differences between the cultivars in total yield, bulb diameter, bulb weight, cloves number/bulb and clove weight in the two seasons. Balady cultivar results in the highest values of cloves number per bulb in the two seasons and the highest values of bulbing ratio in the first season. On the contrary, the Chinese cultivar gave the lowest values of clove number. Also, the Balady cultivar gave the lowest values of bulb weight, bulb diameter, as well as clove weight in two seasons. The results of total yield are in agreement with those of Dawood (2011), Abou El-Magd et al., (2012) and Osman (2015) who reported that Sids-40 cultivar recorded the highest yield.

Table 1: Effect of cultivar on some biometric parameters of garlic plants during (2018/2019) and (2019/2020) seasons.

\begin{tabular}{|c|c|c|c|c|c|c|c|}
\hline Cultivar & $\begin{array}{c}\text { Cured yield } \\
\text { (ton/fed.) }\end{array}$ & $\begin{array}{l}\text { Bulb weight } \\
\text { (gm.) }\end{array}$ & $\begin{array}{c}\text { Neck } \\
\text { diameter } \\
(\mathrm{cm})\end{array}$ & $\begin{array}{l}\text { Bulb diameter } \\
\text { (cm) }\end{array}$ & $\begin{array}{l}\text { Bulbing } \\
\text { ratio }\end{array}$ & $\begin{array}{c}\text { cloves } \\
\text { number per } \\
\text { bulb }\end{array}$ & $\begin{array}{c}\text { Clove } \\
\text { weight } \\
\text { (gm.) }\end{array}$ \\
\hline \multicolumn{8}{|c|}{ 2018/2019 season } \\
\hline Balady & $6.666^{\mathrm{b}}$ & $50.12^{b}$ & $0.90^{\mathrm{a}}$ & $5.30^{\mathrm{b}}$ & $0.17^{\mathrm{a}}$ & $36.67^{\mathrm{a}}$ & $1.37^{\mathrm{b}}$ \\
\hline Chinese & $6.953^{\mathrm{b}}$ & $52.28^{\mathrm{b}}$ & $0.92^{\mathrm{a}}$ & $6.18^{\mathrm{a}}$ & $0.15^{\mathrm{b}}$ & $12.33^{\mathrm{c}}$ & $4.24^{\mathrm{a}}$ \\
\hline Sids-40 & $7.980^{\mathrm{a}}$ & $60.00^{\mathrm{a}}$ & $0.80^{\mathrm{b}}$ & $6.10^{\mathrm{a}}$ & $0.13^{\mathrm{b}}$ & $15.67^{b}$ & $4.13^{\mathrm{a}}$ \\
\hline \multicolumn{8}{|c|}{ 2019/2020 season } \\
\hline Balady & $7.315^{\mathrm{b}}$ & $55.00^{\mathrm{b}}$ & $0.77^{\mathrm{a}}$ & $5.50^{\mathrm{a}}$ & $0.14^{\mathrm{a}}$ & $45.00^{\mathrm{a}}$ & $1.22^{\mathrm{c}}$ \\
\hline Chinese & $7.505^{\mathrm{b}}$ & $56.43^{\mathrm{b}}$ & $0.80^{\mathrm{a}}$ & $5.88^{\mathrm{a}}$ & $0.14^{\mathrm{a}}$ & $12.33^{\mathrm{c}}$ & $4.63^{\mathrm{a}}$ \\
\hline Sids-40 & $8.556^{\mathrm{a}}$ & $64.33^{\mathrm{a}}$ & $0.80^{\mathrm{a}}$ & $6.00^{\mathrm{a}}$ & $0.14^{\mathrm{a}}$ & $18.67^{b}$ & $3.45^{\mathrm{b}}$ \\
\hline
\end{tabular}

Means followed by the same letters at the same column were not significantly differed according to Duncan's multiple range test $(\mathrm{P}<0.05)$.

In this respect, the highest yield resulted from the Sids-40 cultivar followed by the Chinese cultivar in the two seasons. While, the lowest values of yield were obtained from the Balady cultivar in both seasons. In the same respect, the Sids- 40 cultivar and Chinese cultivar gave the highest values of bulb weight and bulb diameter in the two seasons. Also, the Chinese cultivar followed by the Sids40 cultivar gave the highest values of cloves weight/ bulb in the first and second seasons. Chinese cultivar gave the highest values of neck diameter in the first season. Results of bulb diameter are agreeing with those obtained by Al-Otayk et al., (2008) who reported that Chinese cultivar gave the highest mean values of bulb diameter. Also, the results of the bulb weight, cloves number and clove weight are in agreement with those of Dawood, (2011), Abdel-Razzak and El-Sharkway (2013), and Osman (2015). 


\subsection{Storability}

Data in Table (2) show that sprouting and decay percentages at room temperature were significantly affected by cultivars, Balady cultivar scored lower values of sprouting and decay percentages than Sids-40 and Chinese cultivars in the first and second seasons. The results are in agreement with those of Osman (2015). Abdel-Razzak and El-Sharkawy (2013) mentioned that, the lowest sprouting and decay percentages were detected in Balady cultivar, indicating their high longevity quite the Chinese one.

Table 2: Effect of cultivar on percentages of bulb sprouting and decay of garlic plants during $(2018 / 2019)$ and $(2019 / 2020)$ seasons.

\begin{tabular}{lcc}
\hline Cultivars & Sprouting \% & Decay\% \\
\hline & $\mathbf{2 0 1 8 / 2 0 1 9}$ season & \\
Balady & $0.01^{\mathrm{b}}$ & $0.02^{\mathrm{b}}$ \\
Chinese & $0.29^{\mathrm{a}}$ & $0.13^{\mathrm{a}}$ \\
Sids-40 & $0.05^{\mathrm{b}}$ & $0.10^{\mathrm{a}}$ \\
\hline & $\mathbf{2 0 1 9 / 2 0 2 0}$ season & \\
Balady & $0.02^{\mathrm{b}}$ & $0.02^{\mathrm{b}}$ \\
Chinese & $0.26^{\mathrm{a}}$ & $0.10^{\mathrm{a}}$ \\
Sids-40 & $0.04^{\mathrm{b}}$ & $0.09^{\mathrm{a}}$ \\
\hline
\end{tabular}

Means followed by the same letters at the same column were not significantly differed according to Duncan's multiple range test $(\mathrm{P}<0.05)$.

This superiority of Balady and Sids-40 cultivars in bulbs storage ability could be attributed to the high bulb TSS percentage (Table 6) and carbohydrates assimilation produced by these cultivars.

\subsection{Chemical composition}

Fig. (1) Shows the proximate analysis of different garlic cultivars. The result indicated that the highest moisture content of the Chinese cultivar followed by the Sids-40 cultivar. While, the lowest moisture content was recorded by the Balady cultivar. On the other hand, Balady cultivar. recorded the highest amount of carbohydrate, fat, and ash, respectively, except crude protein of Sids-40 which had the highest value. These significant differences in chemical constituents could be due to the cultivars, The obtained results in this study are in agreement with those of Odebunmi et al., (2009) who concluded that garlic contains $66.57,7.87,0.52,0.73,1.33$, and $33.43 \%$ of moisture, protein, fat, ash and dry matter, respectively and the report of Marina et al., (2014) who reported that garlic contains $64.58 \%$ moisture, $7.87 \%$ protein, $0.52 \%$ ether extract, $2.46 \%$ ash contents, respectively, on a fresh weight basis.

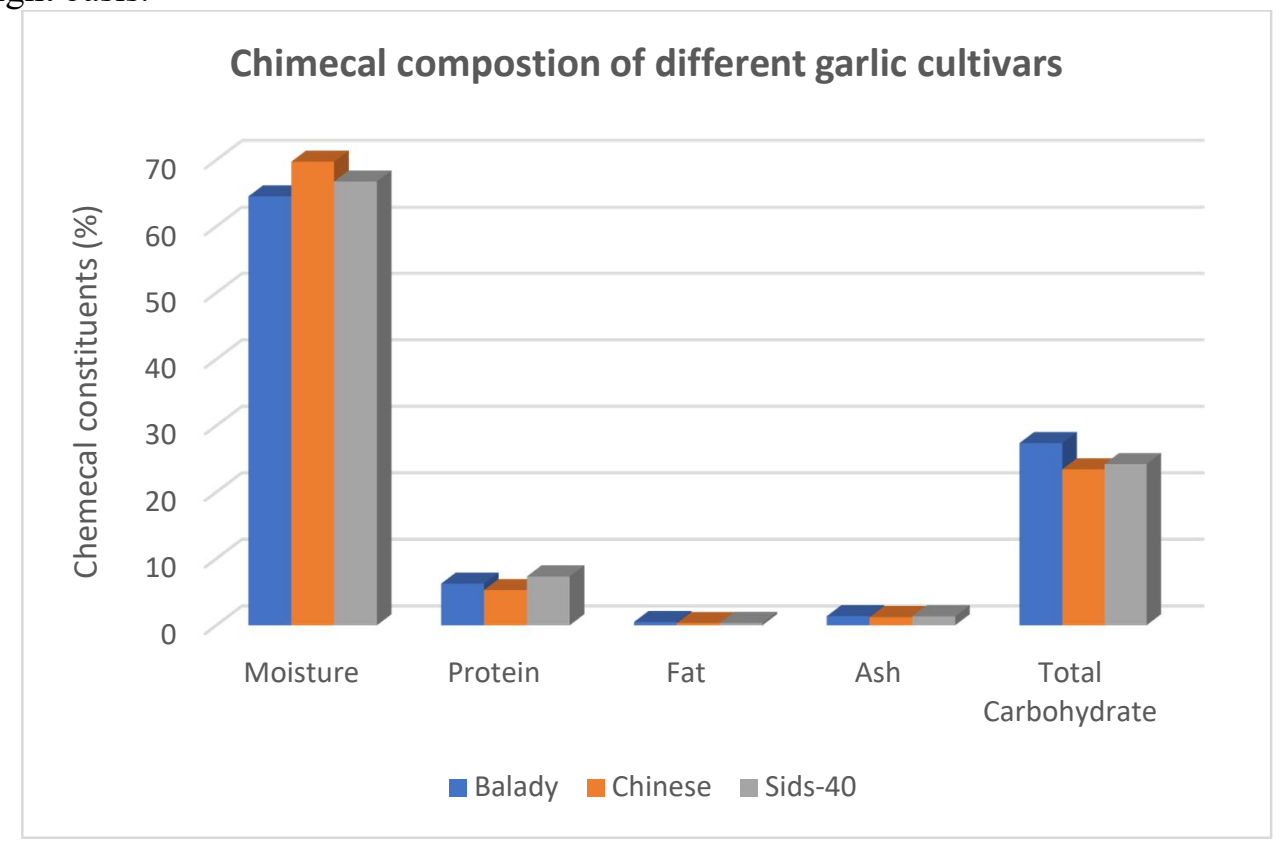

Fig. 1: Proximate composition of different garlic cultivars. 
3.4. Effect of garlic cultivars, technological treatments, and storage periods (day) on moisture content during cold storage.

The moisture content is considered as an important factor in maintaining product quality. The rate of moisture loss from the commodities depends upon the water pressure deficit between the commodity and therefore the surrounding ambient air, which is influenced by the low temperature and relative humidity.

Table 3: Effect of garlic cultivars, treatments, and storage periods (day) on moisture content (\%) during cold storage at $4^{\circ} \mathrm{C}$.

\begin{tabular}{|c|c|c|c|c|c|}
\hline \multirow{2}{*}{ Cultivars } & & \multicolumn{4}{|c|}{ Storage periods (day) } \\
\hline & & Zero time & 90 & 180 & 270 \\
\hline \multirow{4}{*}{ Balady } & Cont. & $64.52^{\mathrm{hl}}$ & $62.83^{\text {Ip }}$ & $61.46^{\mathrm{pq}}$ & $60.07^{r}$ \\
\hline & T1 & $64.55^{\mathrm{hl}}$ & $63.76^{\mathrm{kn}}$ & $62.66^{\mathrm{mp}}$ & $61.86^{\mathrm{pq}}$ \\
\hline & $\mathbf{T 2}$ & $64.55^{\mathrm{hl}}$ & $64.08^{\mathrm{im}}$ & $63.75^{\mathrm{kn}}$ & $62.26^{\mathrm{nq}}$ \\
\hline & T3 & $64.52^{\mathrm{hl}}$ & $64.13^{\text {im }}$ & $63.87^{\mathrm{jm}}$ & $62.65^{\mathrm{mp}}$ \\
\hline \multirow{4}{*}{ Chinese } & Cont. & $69.74^{\mathrm{a}}$ & $66.32^{\mathrm{dg}}$ & $64.33^{\mathrm{im}}$ & $62.94^{\text {Ip }}$ \\
\hline & T1 & $69.75^{\mathrm{a}}$ & $68.15^{\mathrm{bc}}$ & $67.85^{\text {bd }}$ & $66.56^{\mathrm{cf}}$ \\
\hline & $\mathbf{T} 2$ & $69.76^{\mathrm{a}}$ & $68.65^{\mathrm{ab}}$ & $67.76^{\mathrm{be}}$ & $66.68^{\mathrm{cf}}$ \\
\hline & T3 & $69.73^{a}$ & $68.93^{\mathrm{ab}}$ & $67.90^{\text {bd }}$ & $66.86^{\mathrm{cf}}$ \\
\hline \multirow{4}{*}{ Sids-40 } & Cont. & $66.76^{\mathrm{cf}}$ & $64.75^{\text {hk }}$ & $62.14^{\mathrm{oq}}$ & $60.96^{\mathrm{qr}}$ \\
\hline & T1 & $66.76^{\mathrm{cf}}$ & $65.54^{\mathrm{fg}}$ & $64.15^{\mathrm{im}}$ & $63.54^{\mathrm{ko}}$ \\
\hline & $\mathbf{T 2}$ & $66.75^{\mathrm{cf}}$ & $66.07^{\text {fh }}$ & $65.27^{\mathrm{fk}}$ & $64.17^{\mathrm{im}}$ \\
\hline & T3 & $66.74^{\mathrm{cf}}$ & $66.16^{\mathrm{eh}}$ & $65.62^{\mathrm{fi}}$ & $64.88^{\mathrm{gk}}$ \\
\hline \multirow{2}{*}{\multicolumn{2}{|c|}{ Mean of Cultivars }} & Balady & Chinese & Sids-40 & \\
\hline & & $63.22^{\mathrm{c}}$ & $67.62^{\mathrm{a}}$ & $65.02^{\mathbf{b}}$ & \\
\hline \multirow{2}{*}{\multicolumn{2}{|c|}{ Mean of treatments }} & Cont. & T1 & T2 & T3 \\
\hline & & $63.90^{\mathrm{c}}$ & $65.43^{\mathrm{b}}$ & $65.81^{\mathrm{a}}$ & $65.99^{\mathrm{a}}$ \\
\hline \multirow{2}{*}{\multicolumn{2}{|c|}{ Mean of storage periods(day) }} & Zero Time & 90 & 180 & 270 \\
\hline & & $67.01^{\mathrm{a}}$ & $65.78^{\mathrm{b}}$ & $64.73^{\mathrm{c}}$ & $63.62^{\mathrm{d}}$ \\
\hline
\end{tabular}

*Values are means of triplicate samples $(\mathrm{n}=3)$ Means with different letters $(\mathrm{a}, \mathrm{b}, \mathrm{c} \ldots)$ indicate significant differences $(\mathrm{P}<0.05)$.

** (T1) Carrageenan + potassium sorbate. (T2) Chitosan + potassium sorbate. (T3) Chitosan + Carrageenan + potassium sorbate.

The effect of cultivars, technological treatments, and cold storage periods (day) on moisture contents of different garlic cultivars was studied and the data in Table (3) show that there were significant differences between cultivars, technological treatments and storage periods on moisture content. In this respect, the highest moisture content found in the Chinese cultivar followed by the Sids-40 cultivar. While, the lowest moisture content was recorded by the Balady cultivar.

In the same respect, the recorded data in the same table show that, the good effect of the technological treatments was recorded to the treatments No $(3,2)$ respectively, the accumulative moisture loss within the different garlic cultivar with different technological treatments during cold storage as influenced by the cold storage conditions. The results indicate that the moisture loss of control samples was more than the moisture loss of coated samples during the storage. These obtained results may be due to using of coating materials which led to reduce (a) the vapor pressure differences between the air surrounding the product and the vapor pressure inside the product, (b) the free water evaporating from the product surface due to the moisture gradient between the air surrounding the product and the product moisture. These results were in good agreement with Asgar et al. (2011) who recorded that chitosan provided an effective control in reducing moisture vapor, delayed changes in the peel color. 
3.5. Effect of garlic cultivars, treatments and storage periods (day) on total soluble solids (TSS $\%)$ during cold storage.

TSS of different garlic cultivars. was significantly affected by cultivars, edible coating treatments, the cold storage period, and their interactions. Both edible coated and control samples showed increased TSS; however, edible coating treatments significantly delayed increment in TSS of various garlic cultivars during cold storage period. After 270 days of storage, a very little increase in TSS was observed in treatment No (3) followed by treatment No (2), compared to control. The obtained results in Table (4) show that the highest amount of TSS was recorded to Balady cultivar followed by Sids-40, meanwhile, the lowest levels of TSS were recorded to Chinese cultivar. These results may be due to the slowing down of respiration and metabolic activity, and the increase in TSS in untreated garlic cultivars could be due to the volatility of soluble compounds and water at a faster rate due to the lack of protecting barriers. A lower increase in TSS of coated garlic cultivars. might be due to delayed ripening. Our results were in agreement with Ali et al. (2010) who noticed that coating treatment delayed changes in soluble solids of tomato. On the other hand, the decrease in TSS is thought to be resulted from the breakdown of sugars in association with respiration rate. This, also, recorded by Özden and Bayindirli (2002) and Torun (2015) in green peppers and garlic.

Table 4: Effect of garlic cultivars, treatments, and storage periods (day) on total soluble solids (TSS $\%$ ) during cold storage at $4^{\circ} \mathrm{C}$.

\begin{tabular}{|c|c|c|c|c|c|}
\hline \multirow{2}{*}{ Cultivars } & & \multicolumn{4}{|c|}{ Storage periods (day) } \\
\hline & & Zero time & 90 & 180 & 270 \\
\hline \multirow{4}{*}{ Balady } & Cont. & $34.53^{\mathrm{e}}$ & $35.38^{\mathrm{cd}}$ & $36.12^{b}$ & $36.56^{\mathrm{a}}$ \\
\hline & T1 & $34.50^{\mathrm{e}}$ & $34.56^{\mathrm{e}}$ & $35.09^{d}$ & $35.58^{\mathrm{cd}}$ \\
\hline & $\mathbf{T 2}$ & $34.42^{\mathrm{e}}$ & $35.12^{d}$ & $35.49^{\mathrm{cd}}$ & $35.69^{c}$ \\
\hline & T3 & $34.42^{\mathrm{e}}$ & $34.11^{\text {ef }}$ & $34.52^{\mathrm{e}}$ & $34.55^{\mathrm{e}}$ \\
\hline \multirow{4}{*}{ Chinese } & Cont. & $31.57^{\mathrm{k}}$ & $32.40^{\mathbf{j}}$ & $33.53^{\text {gh }}$ & $33.86^{\mathrm{fg}}$ \\
\hline & T1 & $31.47^{\mathbf{k}}$ & $32.15^{\mathbf{j}}$ & $32.30^{\mathbf{j}}$ & $32.63^{\mathrm{ij}}$ \\
\hline & $\mathbf{T 2}$ & $31.49^{k}$ & $32.21^{\mathrm{j}}$ & $32.59^{\mathrm{ij}}$ & $33.50^{\mathrm{gh}}$ \\
\hline & T3 & $31.60^{\mathrm{k}}$ & $31.53^{\mathrm{k}}$ & $32.44^{\mathrm{j}}$ & $32.37^{\mathbf{j}}$ \\
\hline \multirow{4}{*}{ Sids-40 } & Cont. & $32.13^{\mathrm{j}}$ & $32.60^{\mathrm{ij}}$ & $33.55^{\mathrm{gh}}$ & $34.50^{\mathrm{e}}$ \\
\hline & T1 & $32.33^{\mathbf{j}}$ & $32.48^{\mathrm{ij}}$ & $32.50^{\mathrm{ij}}$ & $33.07^{\text {hi }}$ \\
\hline & $\mathbf{T 2}$ & $32.27^{\mathbf{j}}$ & $32.42^{\mathrm{j}}$ & $32.48^{\mathrm{ij}}$ & $33.50^{\mathrm{gh}}$ \\
\hline & T3 & $32.20^{\mathbf{j}}$ & $32.25^{\mathrm{j}}$ & $32.31^{\mathbf{j}}$ & $32.54^{\mathrm{ij}}$ \\
\hline \multirow{2}{*}{\multicolumn{2}{|c|}{ Mean of Cultivars }} & Balady & Chinese & Sids-40 & \\
\hline & & $35.04^{\mathrm{a}}$ & $32.35^{\mathrm{c}}$ & $32.69^{\mathbf{b}}$ & \\
\hline \multirow{2}{*}{\multicolumn{2}{|c|}{ Mean of treatments }} & Cont. & T1 & $\mathbf{T 2}$ & T3 \\
\hline & & $33.89^{\mathrm{a}}$ & $33.22^{\mathbf{b}}$ & $33.43^{\mathrm{ab}}$ & $32.90^{\mathbf{b}}$ \\
\hline \multirow{2}{*}{\multicolumn{2}{|c|}{ Mean of storage periods(day) }} & Zero Time & 90 & 180 & 270 \\
\hline & & $32.74^{\mathrm{c}}$ & $33.10^{\mathbf{b c}}$ & $33.58^{\mathrm{ab}}$ & $34.03^{\mathrm{a}}$ \\
\hline
\end{tabular}

*Values are means of triplicate samples $(n=3)$ Means with different letters $(a, b, c \ldots)$ indicate significant differences $(\mathrm{P}<0.05)$.

** (T1) Carrageenan + potassium sorbate. (T2) Chitosan + potassium sorbate. (T3) Chitosan + Carrageenan + potassium sorbate.

\subsection{Effect of garlic cultivars, treatments, and storage periods (day) on total pungency contents during cold storage.}

In this study, the pungency content was significantly affected by cultivars, edible coating treatments, the cold storage period and their interactions. The highest amount of pungency was recorded to Balady cultivar. Followed by Sids-40, meanwhile, the lowest levels of pungency were recorded to Chinese cultivar. The obtained results in Table (5) showed a significant decrease in pungency levels in all cultivars and treatments. While the lower storage temperature and edible coating treatments helped for keeping pungency content during the cold storage period of $270^{\text {th }}$ day. 
The treatment No (3) was the best for keeping pungency content followed by treatment No (2) compared to the control sample. The highest amount of pungency was recorded to Balady cultivar. Followed by Sids-40, meanwhile, the lowest levels of pungency were recorded to Chinese cultivar.

Furthermore, pungency decreased rapidly during the cold storage period and these results may be due to be associated with the conversion of allicin to the allylsulfide, vinildithine, and ajoene, because allicin is not stable during long cold storage period in the case of uncoating samples. These results are agreeing with EL-Sayed et al. (2020) who reported that, pungency content of different cultivars. ranged from (6.04 to $9.38 \mu \mathrm{mol} / \mathrm{g}$ ) on a fresh weight basis.

Table 5: Effect of garlic cultivars, treatments and storage period (day) on total pungency contents ( $\mu \mathrm{mol} / \mathrm{g}$ on fresh weight basis) during cold storage at $4^{\circ} \mathrm{C}$.

\begin{tabular}{|c|c|c|c|c|c|}
\hline \multirow{2}{*}{ Cultivars } & & \multicolumn{4}{|c|}{ Storage periods (day) } \\
\hline & & Zero time & 90 & 180 & 270 \\
\hline \multirow{4}{*}{ Balady } & Cont. & $8.01^{\mathrm{a}}$ & $6.37^{\mathrm{df}}$ & $5.09^{\mathrm{jl}}$ & $4.84^{\mathrm{km}}$ \\
\hline & T1 & $7.93^{\mathrm{a}}$ & $6.75^{\mathrm{cd}}$ & $5.64^{\mathrm{gj}}$ & $5.36^{\mathrm{ik}}$ \\
\hline & $\mathrm{T} 2$ & $7.91^{\mathbf{a}}$ & $6.84^{\mathrm{bd}}$ & $5.65^{\mathrm{gj}}$ & $5.36^{\mathrm{ik}}$ \\
\hline & $\mathbf{T 3}$ & $7.94^{\mathrm{a}}$ & $6.96^{\mathrm{bc}}$ & $5.92^{\mathrm{fi}}$ & $5.54^{\mathrm{gj}}$ \\
\hline \multirow{4}{*}{ Chinese } & Cont. & $6.64^{\mathrm{ce}}$ & $5.33^{\mathrm{ik}}$ & $4.66^{\mathrm{Im}}$ & $3.56^{\mathrm{n}}$ \\
\hline & T1 & $6.63^{\mathrm{ce}}$ & $5.45^{\mathrm{ik}}$ & $5.34^{\mathrm{ik}}$ & $5.15^{\mathrm{jl}}$ \\
\hline & $\mathrm{T} 2$ & $6.62^{\mathrm{ce}}$ & $5.64^{\mathrm{gj}}$ & $5.46^{\mathrm{ik}}$ & $5.34^{\mathrm{ik}}$ \\
\hline & $\mathbf{T 3}$ & $6.78^{\mathrm{cd}}$ & $6.14^{\mathrm{eh}}$ & $5.45^{\mathrm{ik}}$ & $5.34^{i \mathrm{k}}$ \\
\hline \multirow{4}{*}{ Sids-40 } & Cont. & $7.34^{\mathrm{b}}$ & $6.15^{\mathrm{eg}}$ & $5.05^{\mathrm{jl}}$ & $4.46^{\mathrm{m}}$ \\
\hline & T1 & $7.38^{\mathrm{b}}$ & $6.35^{\mathrm{df}}$ & $5.53^{\mathbf{h j}}$ & $5.44^{i \mathrm{k}}$ \\
\hline & $\mathbf{T 2}$ & $7.37^{\mathrm{b}}$ & $6.35^{\mathrm{df}}$ & $5.66^{\mathrm{gj}}$ & $5.56^{\mathrm{gi}}$ \\
\hline & T3 & $7.36^{\mathbf{b}}$ & $6.44^{\mathrm{cf}}$ & $5.74^{\mathrm{gi}}$ & $5.64^{\mathrm{gi}}$ \\
\hline \multirow{2}{*}{\multicolumn{2}{|c|}{ Mean of Cultivars }} & Balady & Chinese & Sids-40 & \\
\hline & & $6.38^{\mathrm{a}}$ & $5.60^{\mathrm{c}}$ & $6.11^{\mathrm{b}}$ & \\
\hline \multirow{2}{*}{\multicolumn{2}{|c|}{ Mean of treatments }} & Cont. & T1 & $\mathbf{T 2}$ & T3 \\
\hline & & $5.63^{\mathrm{d}}$ & $5.13^{\mathrm{d}}$ & $6.15^{\mathrm{b}}$ & $6.27^{\mathrm{a}}$ \\
\hline \multirow{2}{*}{\multicolumn{2}{|c|}{ Mean of storage periods(day) }} & Zero Time & 90 & 180 & 270 \\
\hline & & $7.32^{\mathrm{a}}$ & $6.23^{b}$ & $5.43^{\mathrm{c}}$ & $5.13^{\mathrm{d}}$ \\
\hline
\end{tabular}

*Values are means of triplicate samples $(n=3)$ Means with different letters $(a, b, c \ldots)$ indicate significant differences $(\mathrm{P}<0.05)$

**(T1) Carrageenan + potassium sorbate. (T2) Chitosan + potassium sorbate. (T3) Chitosan + Carrageenan + potassium sorbate.

\subsection{Effect of garlic cultivars, treatments, and storage periods (day) on weight loss during cold storage.}

Different cultivars, edible coating treatments, and different cold storage periods significantly affected the weight loss of peeled garlic cloves. The weight loss appeared to be the major determinant of storage periods and quality of peeled garlic cloves. Weight loss increased with the progression of the storage period and reached the maximum on the $270^{\text {th }}$ day.

All the edible coating treatments of peeled garlic cloves showed a lower percentage of weight loss than control. Table (6) shows the total weight loss of the garlic during cold storage as affected by the cold storage system, cultivars, and coating treatment. The obtained results indicate that the total weight loss increases in control samples without coating and with the cold storage period. It can be seen after 270 days, of cold storage, the total weight losses ranged from $5.55-9.40 \%$ for the coated samples which were packaged in vacuum plastic bags. While it was as high as 9.50 to $11.45 \%$ for the uncoated samples stored in the same plastic bags at storage system.

The increasing of weight loss gradually throughout cold storage period regardless of treatments, could be due to water loss driven by active metabolic processes, like transpiration and respiration in the peeled garlic cloves (Dronachari et al., 2010). However, the coating of peeled garlic cloves 
maintained a higher weight throughout the cold storage period as compared to uncoated peeled garlic cloves.

Moreover, reduced weight loss in the case of coated peeled garlic cloves could be attributed to the semipermeable effect of coatings during moisture loss, respiration, and movements of solutes across the membrane. The same results were caused in banana fruit (Maqbool et al., 2010). It is evident from this study that coated peeled garlic cloves with chitosan and other coating materials reduced the weight loss compared with the control samples, probably as a result of covering the cuticles on the fruit surfaces. Our results are supported by Pérez-Gagoa et al. (2006).

Table 6: Effect of garlic cultivars, treatments and storage periods (day) on weight loss (\%) during cold storage at $4^{\circ} \mathrm{C}$.

\begin{tabular}{|c|c|c|c|c|c|}
\hline \multirow{2}{*}{ Cultivar } & & \multicolumn{4}{|c|}{ Storage periods (day) } \\
\hline & & Zero time & 90 & 180 & 270 \\
\hline \multirow{4}{*}{ Balady } & Cont. & $0.00^{1}$ & $1.00^{\mathbf{k l}}$ & $5.54^{\mathrm{fg}}$ & $11.17^{\mathrm{ab}}$ \\
\hline & T1 & $0.00^{1}$ & $0.84^{\mathrm{kl}}$ & $4.32^{\mathrm{gi}}$ & $9.40^{\text {bd }}$ \\
\hline & $\mathbf{T 2}$ & $0.00^{1}$ & $0.63^{\mathrm{kl}}$ & $4.91^{\mathrm{gh}}$ & $7.92^{\mathrm{de}}$ \\
\hline & T3 & $0.00^{1}$ & $0.74^{\mathrm{kl}}$ & $1.95^{\mathrm{jl}}$ & $7.14^{\mathrm{ef}}$ \\
\hline \multirow{4}{*}{ Chinese } & Cont. & $0.00^{1}$ & $1.72^{\mathrm{jl}}$ & $4.72^{\mathrm{gh}}$ & $11.45^{\mathrm{a}}$ \\
\hline & T1 & $0.00^{1}$ & $0.95^{\mathrm{kl}}$ & $4.43^{\mathrm{gi}}$ & $10.60^{\mathrm{ac}}$ \\
\hline & $\mathbf{T 2}$ & $0.00^{1}$ & $0.85^{\mathrm{kl}}$ & $3.23^{\mathrm{hj}}$ & $9.02^{\text {cd }}$ \\
\hline & T3 & $0.00^{1}$ & $0.63^{\mathrm{kl}}$ & $1.98^{\mathrm{jl}}$ & $5.87^{\mathrm{fg}}$ \\
\hline \multirow{4}{*}{ Sids-40 } & Cont. & $0.00^{1}$ & $0.82^{\mathrm{kl}}$ & $4.01^{\mathrm{gi}}$ & $9.50^{\text {bd }}$ \\
\hline & T1 & $0.00^{1}$ & $0.70^{\mathrm{kl}}$ & $2.67^{\mathrm{ik}}$ & $8.52^{\mathrm{de}}$ \\
\hline & $\mathbf{T 2}$ & $0.00^{1}$ & $0.43^{\mathrm{kl}}$ & $2.20^{\mathrm{jl}}$ & $5.55^{\mathrm{fg}}$ \\
\hline & T3 & $0.00^{1}$ & $0.40^{\mathrm{kl}}$ & $1.82^{\mathrm{jl}}$ & $8.08^{\mathrm{de}}$ \\
\hline \multirow{2}{*}{\multicolumn{2}{|c|}{ Mean of Cultivars }} & Balady & Chinese & Sids-40 & \\
\hline & & $3.47^{\mathrm{a}}$ & $3.46^{\mathrm{a}}$ & $2.79^{\mathbf{b}}$ & \\
\hline \multirow{2}{*}{\multicolumn{2}{|c|}{ Mean of treatments }} & Cont. & T1 & T2 & T3 \\
\hline & & $4.16^{\mathrm{a}}$ & $3.54^{\mathrm{b}}$ & $2.89^{\mathrm{c}}$ & $2.38^{\mathrm{d}}$ \\
\hline \multirow{2}{*}{\multicolumn{2}{|c|}{ Mean of storage periods(day) }} & Zero Time & 90 & 180 & 270 \\
\hline & & $0.36^{\mathbf{d}}$ & $0.80^{\mathrm{c}}$ & $3.48^{\mathrm{b}}$ & $8.69^{\mathrm{a}}$ \\
\hline
\end{tabular}

*Values are means of triplicate samples $(n=3)$ Means with different letters $(a, b, c \ldots)$ indicate significant differences $(\mathrm{P}<0.05)$.

** (T1) Carrageenan + potassium sorbate. (T2) Chitosan + potassium sorbate. (T3) Chitosan + Carrageenan + potassium sorbate.

\subsection{Effect of garlic cultivars, treatments, and storage periods (day) on firmness (N) during cold storage.}

Fruit and vegetable firmness are a major attribute that dictates the postharvest life and quality of fruit and vegetables.

Table (7) shows the effect of cultivars, edible coating treatments, storage period at low temperature, and their interactions in the quality and shelf life of different garlic cultivars. These factors significantly reduced the loss of firmness in Peeled garlic cloves during cold storage periods especially, in both Balady cultivar and using of chitosan + carrageenan + potassium sorbate treatment No (3).

Meanwhile, the control samples lost their textural integrity faster than the coated samples, which largely maintained the peeled garlic cloves appearance and quality until the end of cold storage periods. Peeled garlic cloves softening may be due to deterioration in the cell structure, the cell wall composition, the intracellular materials and the higher antifungal activity of coating materials. The retention of firmness with different coating materials is in agreement with the results of (Asgar et al., 2005; Martinez-Romero et al., 2006). According to the current study, it could also seem that the effect 
of coating materials depends on variety and storage conditions (temperature, relative humidity and period).

Table 7: Effect of garlic cultivars, treatments and storage periods (day) on firmness $(\mathrm{N})$ during cold storage at $4^{\circ} \mathrm{C}$.

\begin{tabular}{|c|c|c|c|c|c|}
\hline \multirow{2}{*}{ Cultivars } & & \multicolumn{4}{|c|}{ Storage periods (day) } \\
\hline & & Zero time & 90 & 180 & 270 \\
\hline \multirow{4}{*}{ Balady } & Cont. & $9.84^{\mathrm{a}}$ & $9.64^{\mathrm{b}}$ & $9.24^{\mathrm{de}}$ & $9.15^{\mathrm{ef}}$ \\
\hline & T1 & $9.51^{\mathbf{b c}}$ & $9.36^{\mathrm{ce}}$ & $9.18^{\mathrm{ef}}$ & $9.17^{\mathrm{ef}}$ \\
\hline & $\mathrm{T} 2$ & $9.44^{\text {bd }}$ & $9.33^{\text {ce }}$ & $9.17^{\text {ef }}$ & $9.14^{\mathrm{ef}}$ \\
\hline & T3 & $9.45^{\mathbf{b d}}$ & $9.24^{\mathrm{de}}$ & $9.15^{\mathrm{ef}}$ & $9.16^{\mathrm{ef}}$ \\
\hline \multirow{4}{*}{ Chinese } & Cont. & $8.16^{\mathrm{hj}}$ & $7.95^{\mathrm{jl}}$ & $7.84^{\mathrm{km}}$ & $7.65^{\mathrm{m}}$ \\
\hline & T1 & $7.78^{\mathrm{lm}}$ & $7.75^{\mathrm{Im}}$ & $7.74^{1 \mathrm{~m}}$ & $7.62^{\mathrm{m}}$ \\
\hline & T2 & $7.75^{\mathrm{lm}}$ & $7.64^{\mathrm{m}}$ & $7.65^{\mathrm{m}}$ & $7.63^{\mathrm{m}}$ \\
\hline & T3 & $7.75^{\mathrm{lm}}$ & $7.68^{\mathrm{m}}$ & $7.64^{\mathrm{m}}$ & $7.64^{\mathrm{m}}$ \\
\hline \multirow{4}{*}{ Sids-40 } & Cont. & $8.94^{\mathrm{f}}$ & $8.64^{\mathrm{g}}$ & $8.22^{\mathrm{hi}}$ & $8.07^{\mathrm{ij}}$ \\
\hline & T1 & $8.36^{\mathrm{h}}$ & $8.25^{\mathrm{hi}}$ & $8.13^{\mathbf{h j}}$ & $8.05^{\text {ik }}$ \\
\hline & T2 & $8.23^{\mathrm{hi}}$ & $8.25^{\mathrm{hi}}$ & $8.14^{\mathbf{h j}}$ & $8.04^{\mathrm{ik}}$ \\
\hline & T3 & $8.24^{\text {hi }}$ & $8.24^{\text {hi }}$ & $8.16^{\mathbf{h j}}$ & $8.05^{\text {ik }}$ \\
\hline \multirow{2}{*}{\multicolumn{2}{|c|}{ Mean of Cultivars }} & Balady & Chinese & Sids-40 & \\
\hline & & $9.32^{\mathrm{a}}$ & $7.74^{\mathrm{c}}$ & $8.25^{\mathbf{b}}$ & \\
\hline \multirow{2}{*}{\multicolumn{2}{|c|}{ Mean of treatments }} & Cont. & T1 & $\mathbf{T 2}$ & T3 \\
\hline & & $8.37^{\mathbf{b}}$ & $8.37^{\mathbf{b}}$ & $8.41^{\mathrm{b}}$ & $8.61^{\mathrm{a}}$ \\
\hline \multirow{2}{*}{\multicolumn{2}{|c|}{ Mean of storage periods(day) }} & Zero Time & 90 & 180 & 270 \\
\hline & & $8.62^{\mathrm{a}}$ & $8.50^{\mathbf{b}}$ & $8.35^{\mathrm{c}}$ & $8.28^{\mathrm{c}}$ \\
\hline
\end{tabular}

*Values are means of triplicate samples $(\mathrm{n}=3)$ Means with different letters $(\mathrm{a}, \mathrm{b}, \mathrm{c} \ldots)$ indicate significant differences $(\mathrm{P}<0.05)$.

** (T1) Carrageenan + potassium sorbate. (T2) Chitosan + potassium sorbate. (T3) Chitosan +Carrageenan + potassium sorbate.

\subsection{Effect of garlic cultivars, treatments, and storage periods (day) on the microbial quality during cold storage.}

The effect of different treatments of coating materials, cultivars, and cold storage periods on microbial counts (total bacterial count, yeast and mold, and psychrophilic bacteria counts) of peeled garlic cloves were presented in Table (8).

It was noticed that treatment. No (3) was the most effective treatment in inhibiting microbial growth at the end of cold storage periods $\left(270^{\text {th }}\right.$ day) at all garlic cultivars. From the previously mentioned results in Table (8) it could be concluded that using of different edible coating materials and storage at low temperature, to extend shelf life of peeled garlic cloves using of chitosan +carrageenan with the incorporation of potassium sorbate, prolonged the shelf life to 270 day of cold storage. These results are in agreement with those obtained by Campos et al., (2012) who stated that edible coating provided reductions in counts of psychrophilic microorganisms on cold stored strawberry fruits. (Parra et al., 2014 and Abed EL-Hakim, 2017) stated that potassium sorbate either alone or in mixture as the carrier had the potential to be environmentally compatible, nontoxic postharvest fungicides to be used against citrus mold.

Moreover, all garlic groups had high content of acidity during storage because of microbial activity caused by penicillium spp. The penicillium spp. supplies acidity in the garlic cloves during storage. Also, Yage Xing et al. (2016) reported that chitosan is always used as a potential food preservative which might be due to its antimicrobial activity against a variety of foodborne bacteria, yeast, and fungi. 
Table 8: Effect of garlic cultivars, treatments and storage periods (day) on microbial counts (CFU/g) during cold storage at $4^{\circ} \mathrm{C}$.

\begin{tabular}{|c|c|c|c|c|c|c|c|c|c|c|c|c|c|}
\hline \multirow[b]{3}{*}{ Cultivars } & \multirow{3}{*}{ Treat. } & \multicolumn{4}{|c|}{ Total count } & \multicolumn{4}{|c|}{ Yeast and mold } & \multicolumn{4}{|c|}{ Psychrophilic } \\
\hline & & \multicolumn{12}{|c|}{ Storage periods (day) } \\
\hline & & zero time & 90 & 180 & 270 & zero time & 90 & 180 & 270 & zero time & 90 & 180 & 270 \\
\hline \multirow{4}{*}{ Balady } & Cont. & $2 \times 10^{2}$ & $3.8 \times 10^{2}$ & $5.6 \times 10^{2}$ & $7.9 \times 10^{2}$ & $1.1 \times 10^{2}$ & $1.6 \times 10^{2}$ & $3.3 \times 10^{2}$ & $5.9 \times 10^{2}$ & $1.5 \times 10^{2}$ & $3.6 \times 10^{3}$ & $4.2 \times 10^{4}$ & $7.0 \times 10^{4}$ \\
\hline & T1 & $2.4 \times 10^{2}$ & $2.8 \times 10^{2}$ & $3.7 \times 10^{2}$ & $5.0 \times 10^{2}$ & $0.8 \times 10^{2}$ & $1.0 \times 10^{2}$ & $1.4 \times 10^{2}$ & $2.0 \times 10^{2}$ & $1.2 \times 10^{2}$ & $1.6 \times 10^{2}$ & $1.7 \times 10^{2}$ & $2.4 \times 10^{2}$ \\
\hline & $\mathbf{T} 2$ & $1.8 \times 10^{2}$ & $2.3 \times 10^{2}$ & $3.2 \times 10^{2}$ & $4.6 \times 10^{2}$ & $0.9 \times 10^{2}$ & $1.4 \times 10^{2}$ & $1.9 \times 10^{2}$ & $2.1 \times 10^{2}$ & $1.4 \times 10^{2}$ & $1.7 \times 10^{2}$ & $1.9 \times 10^{2}$ & $2.6 \times 10^{2}$ \\
\hline & T3 & $2.3 \times 10^{2}$ & $2.5 \times 10^{2}$ & $3.4 \times 10^{2}$ & $4.9 \times 10^{2}$ & $1.1 \times 10^{2}$ & $1.3 \times 10^{2}$ & $1.6 \times 10^{2}$ & $1.9 \times 10^{2}$ & $1.6 \times 10^{2}$ & $1.8 \times 10^{2}$ & $2.2 \times 10^{2}$ & $2.3 \times 10^{2}$ \\
\hline \multirow{4}{*}{ Chinese } & Cont. & $2.5 \times 10^{1}$ & $3 \times 10^{3}$ & $5.2 \times 10^{4}$ & $9.1 \times 10^{4}$ & $2 \times 10^{1}$ & $3.3 \times \times 10^{2}$ & $6.4 \times 10^{2}$ & $10.1 \times 10^{2}$ & $0.6 \times 10^{2}$ & $2.9 \times 10^{2}$ & $4.4 \times 10^{2}$ & $8.9 \times 10^{2}$ \\
\hline & $\mathbf{T 1}$ & $2.4 \times 10^{2}$ & $2.8 \times 10^{2}$ & $3.5 \times 10^{2}$ & $4.4 \times 10^{2}$ & $1.1 \times 10^{2}$ & $1.2 \times 10^{2}$ & $1.7 \times 10^{2}$ & $2.4 \times 10^{2}$ & $1.0 \times 10^{2}$ & $1.3 \times 10^{2}$ & $2.1 \times 10^{2}$ & $2.9 \times 10^{2}$ \\
\hline & $\mathbf{T} 2$ & $2.4 \times 10^{2}$ & $2.9 \times 10^{2}$ & $3.6 \times 10^{2}$ & $4.6 \times 10^{2}$ & $1.1 \times 10^{2}$ & $1.3 \times 10^{2}$ & $2.1 \times 10^{2}$ & $2.7 \times 10^{2}$ & $1.4 \times 10^{2}$ & $2.7 \times 10^{2}$ & $3.6 \times 10^{2}$ & $3.6 \times 10^{2}$ \\
\hline & T3 & $2 \times 10^{2}$ & $2.6 \times 10^{2}$ & $3.5 \times 10^{2}$ & $4.0 \times 10^{2}$ & $1.0 \times 10^{2}$ & $1.3 \times 10^{2}$ & $1.8 \times 10^{2}$ & $2.2 \times 10^{2}$ & $1.1 \times 10^{2}$ & $1.5 \times 10^{2}$ & $2.4 \times 10^{2}$ & $2.7 \times 10^{2}$ \\
\hline \multirow{4}{*}{ Sids-40 } & Cont. & $1.5 \times 10^{2}$ & $2.4 \times 10^{2}$ & $6.2 \times 10^{2}$ & $8.4 \times 10^{2}$ & $0.9 \times 10^{2}$ & $1.8 \times 10^{2}$ & $3.9 \times 10^{2}$ & $6.4 \times 10^{2}$ & $2.0 \times 10^{2}$ & $3.4 \times 10^{2}$ & $5.7 \times 10^{2}$ & $7.4 \times 10^{2}$ \\
\hline & T1 & $2.5 \times 10^{2}$ & $2.8 \times 10^{2}$ & $3.2 \times 10^{2}$ & $4.3 \times 10^{2}$ & $0.9 \times 10^{1}$ & $1.2 \times 10^{2}$ & $1.6 \times 10^{2}$ & $2.4 \times 10^{2}$ & $1 \times 10^{1}$ & $1.3 \times 10^{1}$ & $1.6 \times 10^{2}$ & $2.1 \times 10^{2}$ \\
\hline & $\mathbf{T} 2$ & $2.4 \times 10^{2}$ & $3.0 \times 10^{2}$ & $3.6 \times 10^{2}$ & $4.9 \times 10^{2}$ & $2 \times 10^{1}$ & $2.3 \times \times 10^{2}$ & $2.6 \times 10^{2}$ & $2.9 \times 10^{2}$ & $1.4 \times 10^{2}$ & $1.7 \times 10^{2}$ & $2.5 \times 10^{2}$ & $2.9 \times 10^{2}$ \\
\hline & T3 & $2 \times 10^{1}$ & $3.1 \times 10^{1}$ & $3.5 \times 10^{2}$ & $3.8 \times 10^{2}$ & $1.3 \times 10^{2}$ & $1.4 \times 10^{2}$ & $1.8 \times 10^{2}$ & $2.3 \times 10^{2}$ & $1.5 \times 10^{2}$ & $1.7 \times 10^{3}$ & $1.9 \times 10^{4}$ & $2.5 \times 10^{4}$ \\
\hline
\end{tabular}

*Values are means of triplicate samples $(\mathrm{n}=3)$ Means with different letters $(\mathrm{a}, \mathrm{b}, \mathrm{c} \ldots)$ indicate significant differences $(\mathrm{P}<0.05)$

**(T1) Carrageenan + potassium sorbate. (T2) Chitosan + potassium sorbate. (T3) Chitosan +Carrageenan + potassium sorbate. 


\section{Conclusions}

It could be concluded that garlic cultivars, combined effects of different cold storage periods and edible coating treatments-maintained quality and storage life of peeled garlic cloves longer than control. Treated garlic cloves with different edible coating materials could be stored at $4{ }^{\circ} \mathrm{C}$ for up to 270 days. Moreover, results indicated that Chitosan +Carrageenan containing potassium sorbate at low temperature could be a promising treatment for extending storage life and maintaining postharvest quality of peeled garlic cloves, especially for Balady and Sids- 40 cultivars.

\section{References}

Abdel-Razzak, H.S. and G.A. El-Sharkawy, 2013. Effect of biofertilizer and humic acid applications on growth, yield, quality, and storability of two garlic (Allium sativum L.) cultivars. Asian J. of Crop Sci., 5(1): 48-64.

Abed EL-Hakim, H.I., 2017. Improvement of Shelf Life and Physicochemical Quality of Fresh-Cut Green Bean Pods (Phaseolus vulgaris L. cv. Polista) Using Edible Coatings. Journal of Food Sciences; Suez Canal University. 4 (1): 1-10.

Abou El-Magd, M.M., T. El-Shourbagy and S.M. Shehata, 2012. A comparative study on the productivity of four Egyptian garlic cultivars grown under various organic materials in comparison to conventional chemical fertilizer. Aust. J. Basic and Applied Sci., 6(3): 415421.

Ali, A., M. Maqbool, S. Ramachandran, and P.G. Alderson, 2010. Gum arabic as a novel edible coating for enhancing shelf-life and improving postharvest quality of tomato (Solanum Lycopersicum L.) fruit. Postharvest Biology and Technology, 58(1): 42-47.

Al-Otayk, S., M.Z. El-Shinawy and M.I. Motawei., 2008. Variation in productive characteristics and diversity assessment of garlic cultivars and lines using DNA markers. Met., Env. \& Arid Land and Agric. Sci., 20 (1): 63-79.

American Public Health Association, 2001. Compendium of methods for the microbiological examination of foods, Washington. The USA.

AOAC, Association of Official Analytical Chemists, 2012. Official Methods of Analysis Association of Official Analytical Chemists International, 19th edition, Gaithersburg, Maryland, USA.

Asgar, A., T.M.M. Mahmud, S. Kamaruzaman, and Z.A.R. Mohamad, 2005. Effect of chitosan coating on the retention of color development and firmness of papaya fruit during storage. In Proceedings of First International Symposium on Papaya. 22-24 November, Genting Highlands Malaysia.

Asgar, A., T. Mahmud, M. Muda, S. Kamaruzaman, and S. Yasmeen, 2011. Effect of chitosan coatings on the physicochemical characteristics of Eksotika II papaya (Carica papaya L.) fruit during storage Food Chemistry, 124: 620-626.

Bourne, M.C., 2002. Food texture and viscosity. Concept and measurement, 2nd Ed. Academic Press, London. pp. 427.

Campos, R.P., A. Kwiatkowski, C.D. Tonhi and E. Clemente, 2012. Physical-chemical and microbiological characteristics of organic strawberries conserved with biofilms and refrigeration. J. Food Research, 1(3): 247-256.

Cantwell, M.I., 2003. Garlic Recommendations for maintaining postharvest quality. http:/postharvest.ucdavis.edu/Produce/Produce Facts.

Dawood, A.R.A., 2011. A comparative study of growth, yield, and storability of some garlic cultivars and clones under Assiut conditions. M. Sc. Thesis, Fac. Agric., Assiut Univ., Egypt.

Dhall, R.K., 2013. Advances in edible coatings for fresh fruits and vegetables: A review. Critical Review in Food Science \& Nutrition, 53, 435-450. doi:10.1080/10408398.2010.541568.

Dronachari, M., K. Venkatachalapathy and K.S. Rajashekarappa, 2010. Effect of pretreatments and packaging on shelf-life of peeled garlic cloves. Dairying. Foods \& H.S., 29 (2): $130-135$.

EL-Sayed, A.A., Y.M.M. Osman, and H.I. Abd El-Hakim, 2020. Genetic variability and genetic advance from selection in municipal garlic (Allium sativum L.) for economic and quality traits. Egypt. J. Plant Breed, 24(3):511-533.

Gomez, K.A. and A.A. Gomez, 1984. Statistical Procedures for Agricultural Research, 2nd ed. Wiley, New York, 680. 
Han, C., Y. Zhao, S.W. Leonard and M.G. Traber, 2004. Edible coatings to improve storability and frozen enhance the nutritional value of fresh and frozen strawberries (Fragaria ananassa) and raspberries (Rubus ideaus). Postharvest Biology and Technology, 33: 67-78. http:/postharvest.ucdavis.edu/Produce /Produce Facts.

Jiang, Y., J. Li, and W. Jiang, 2005. Effects of chitosan coating on the shelf life of cold-stored litchi fruit at ambient temperature. LWT-Food Science and Technology, 38, 757-761. DOI: 10.1016/j.lwt.2004.09.004

Karbowiak, T., F. Debeaufort, and A. Voilley, 2007. Influence of thermal process on structure and functional properties of emulsion-based edible films. Food Hydrocolloids, 21, 879-888. doi:10.1016/j. foodhyd.2006.07.017

Maqbool, M., A. Ali and P.G. Alderson, 2010. "Effect of cinnamon oil on the incidence of anthracnose disease and postharvest quality of bananas during storage," International Journal of Agriculture and Biology, 12(4): 516-520.

Marina, S., M.S. Butt, B. Masood, A. Shehzad, and S. Tanweer, 2014. Chemical and mineral analysis of garlic: a golden herb. Pakistan Journal of Food Sciences, 24(1):108-110.

Martínez-Romero, D., N. Alburquerqueb, J.M. Valverdea, F. Guilléna, S. Castilloa, D. Valeroa and M. Serranoc, 2006. Postharvest sweet cherry quality and safety maintenance by Aloe vera treatment: A new edible coating. Postharvest Biology and Technology, 39(1): 93-100.

Odebunmi, E.O., O.O. Oluwaniyi and M.O. Bashiru, 2009. Comparative proximate analysis of some food condiments. J. App. Sci. Res., 2(1):1-3.

Osman, Y.M.M., 2015. Effect of some foliar application on yield, quality, and storability of garlic. Ph.D. Thesis, Faculty of Agriculture. Ain Shams University., Egypt, 1-116.

Özden, Ç. and L. Bayindirli, 2002. Effects of combinational use of controlled atmosphere, storage, and edible coating applications on shelf life and quality attributes of green peppers. European Food Research and Technology, 214: 320-326.

Parra, J., G. Ripoll and B. Orihuel-Iranzo, 2014. Potassium sorbate effects on citrus weight loss and decay control. Postharvest Biology and Technology, 96: 7-13.

Pérez-Gagoa, M.B., M. Serra, and M.A. delRíoa, 2006. Postharvest Biology and Technology, 39(1): 84-92.

Ribeiro, C., A.A. Vicente, J.A. Teixeira and C. Miranda, 2007. Optimization of the edible coating composition to retard strawberry fruit senescence. Postharvest Biology \& Technology, 44: 63-70. doi:10.1016/j. postharvbio. 2006.11.015

Schwimmer, S. and W.J. Weston, 1961. Enzymatic development of pyruvic acid in onions and a measure of pungency. J. Agric. Food Chem., 9: 301-304.

Torun, M., 2015. Influence of gamma irradiation and edible coating on the shelf life of peeled garlic stored at different conditions. Akdeniz University $\mathrm{PhD}$ Thesis.

Turhan, K.N., 2009. Is edible coating an alternative to MAP for fresh and minimally processed fruits? X International Controlled and Modified Atmosphere Research Conference, 876, 299-305.

Xing, Y., X. Li, Q. Xu, J. Yun, and Y. Lu, 2010. Antifungal activities of cinnamon oil against Rhizopus nigricans, Aspergillus flavus and Penicillium expansum in vitro and in vivo fruit test. International Journal of Food Science and Technology, 45(9): 1837-1842.

Yage Xing, Q., X.L. Xu, C. Cunkun, S. Li, L. Ma, C. Zhenming and L. Ongbin, 2016. Chitosan-Based Coating with Antimicrobial Agents: Preparation, Property, Mechanism, and Application Effectiveness on Fruits and Vegetables. International Journal of Polymer Science, Article ID 4851730, 24 pages http://dx.doi.org/10.1155/2016/4851730. 